\title{
KEANEKARAGAMAN JENIS TUMBUHAN MASA \\ LAMPAU DI SITUS PEMUTERAN, KABUPATEN \\ BULELENG, PROVINSI BALI \\ (Kajian berdasarkan analisis palinology)
}

\author{
Vita \\ (Puslitbang Arkeologi Nasional) \\ vitamattori@yahoo.co.id
}

\begin{abstract}
ABSTRAK
Berbagai macam jenis tumbuhan yang ada sekarang ini mencerminkan juga bagaimana keanekaragaman jenis tumbuhan yang ada sebelumnya atau di masa lalu, sepanjang keadaan lingkungan daerah tersebut tidak banyak berubah secara signifikan. Komunitas tumbuhan di suatu daerah akan menggambarkan tingkat keanekaragaman jenis tumbuhan yang toleran terhadap kondisi lingkungan daerah tersebut. Daya toleransi jenis tumbuhan terhadap faktor lingkungan tersebut akan berbedabeda yang mengakibatkan adanya perbedaan jenis tumbuhan yang hidup di suatu wilayah.

Dengan menggunakan metode HF dan Acetolysis, maka hasil identifikasi dari fosil polen (pollen analysis) yang telah dilakukan khususnya pada sampel tanah/sedimen yang berasal dari sekitar temuan gerabah, serta pada kotak-kotak ekskavasi yang telah dibuka di Situs Pemuteran, Kabupaten Buleleng. Provinsi Bali secara acak terutama pada lapisan B pada test pit 4 dan 5 , didapatkan jenis fosil pollen dari tumbuhan yang berasal dari tumbuhan yang cukup bermanfaat dari famili Compositae, Poaceae, Malvaceae dan Papilionaceae. Disamping itu terdapat juga butiran pollen yang saat ini tidak terdapat di sekitar situs Pemuteran, seperti famili Pinaceae, Fagaceae, Daphnae, Sequoia, Geraniaceae, Cupressus.
\end{abstract}

Kata kunci: komunitas, pollen, situs Pamuteran.

\section{PLANT DIVERSITY IN THE SITE THEN PEMUTERAN, BULELENG DISTRICT, PROVINCE OF BALI}

(Study Based on Analysis Palinology)

\begin{abstract}
A variety of plant species that exist today reflect the diversity of plant species as well as how pre-existing or in the past, the area along the environmental conditions are not much changed significantly. Plant communities in a region will illustrate the diversity of plant species tolerant to environmental conditions in the area. The power plant tolerance to different
\end{abstract}


environmental factors will lead to different types of plants that live in the area

By using HF method and Acetolysis, then the results of the identification of fossil pollen (pollen analysis) that has been done specifically on a sample of soil /sediment from the findings of pottery, as well as the box has been opened at the excavation site Pemuteran, Buleleng Regency, Bali Province randomly, especially in layer B in test pit 4 and 5 , the types derived from fossil pollen from plants derived from plants that are useful in the family Compositae, Poaceae, Malvaceae and Papilionaceae. In addition, there is also a pollen that is not available on the site around Pemuteran, such as the family Pinaceae, Fagaceae, Daphnae, Sequoia, Geraniaceae, Cupressus.

Keyword: community, pollen, Pemuteran site.

\section{PENDAHULUAN}

Berbicara masalah komunitas tumbuhan di suatu daerah, maka kita akan membayangkan suatu lahan yang ditumbuhi oleh berbagai macam jenis tumbuhan. Keberadaan aneka jenis tumbuhan ini tidak terlepas dari tempat tumbuh dan adaptasi tumbuhan terhadap lingkungannya. Berbagai macam jenis tumbuhan yang ada sekarang ini mencerminkan juga bagaimana keanekaragaman jenis tumbuhan yang ada sebelumnya sepanjang keadaan lingkungan daerah tersebut tidak banyak berubah secara signifikan.

Seperti diketahui bahwa Situs Pemuteran terletak di pantai Utara Bali tepatnya di Kabupaten Buleleng, Provinsi Bali. Menurut Suantika (1998), wilayah pantai Utara Bali ini sampai saat ini telah terbukti merupakan suatu kawasan yang sangat kaya dengan peninggalan arkeologi yang umumnya berasal dari masa prasejarah, klasik, dan Islam yang oleh R.P. Soejono (1977) dinyatakan, pantai selatan Gilimanuk terdapat situs pemukiman dan nekropolis. Hal ini dapat dibuktikan dengan terdapatnya sisa-sisa/bekas bangunan pemujaan, benda-benda yang terbuat dari tanah liat periuk polos dan hias dengan ukuran yang bervariasi, piring, kendi, keramik, benda-benda logam seperti tajak, kapak, gelang, anting-anting, manik-manik, cangkang kerang sebagai sisa makanan serta sisa kehidupan lainnya antara lain pancing dan bandul jaring, serta artefak-artefak yang biasanya ditemukan dalam konteks kubur.

Sebaran situs kubur yang begitu luas di sepanjang pantai utara Bali dari barat sampai ke Timur dengan jumlah dan jenis yang bervariasi serta konsentrasi terbesar di daerah Gilimanuk, maka dapat diasumsikan bahwa situs Gilimanuk adalah sebagai pusat kegiatan berbagai tipe kegiatan terutama dari situs-situs kubur yang terdapat di sepanjang pantai utara Bali (Triwujani, 2007). Sistim penguburan di daerah pantai Utara Bali ini merupakan sistim kubur terbuka/tempayan, seperti kubur-kubur di Gilimanuk yang kira-kira berkembang lebih kurang 2000 - 2500 tahun yang 
lampau yang kadang-kadang disebut sebagai masa pra Hindu (Mahaviranata, 1992).

Adanya berbagai aktivitas penduduk di masa lampau ini, maka perlu untuk diketahui pula bagaimana keadaan lingkungan terutama keanekaragaman jenis tumbuhan di masa itu sebagai salah satu pendukung pemukiman serta kehidupan penduduk di situs ini. Penelitian di situs Pemuteran ini diawali dengan adanya informasi penduduk ketika akan membangun septic tank dan kolam yang menemukan kubur tiga individu primer dengan bekal kubur periuk di villa 14 kompleks Hotel Taman Sari. Salah satu individu tersebut diketahui berkelamin laki-laki, sedangkan individu lainnya tidak dapat diamati karena sudah dibakar oleh penduduk setempat. Selanjutnya penelitian dilakukan pada lokasi yang jaraknya tidak berapa jauh dari lokasi hotel, tepatnya pada lahan milik Bapak Milo Lemo yang berada di tepi pantai. Pada lokasi ini ditemukan artefak berupa kereweng polos dan hias. Begitu juga daerah di sekitar lokasi ini terdapat temuan permukaan berupa gerabah dan manik-manik. Hasil ekskavasi yang dilakukan di Pemuteran ini berupa pecahan gerabah, sisa cangkang moluska dari kelas Pelecypoda dan Gastropoda.

Menurut Triwurjani (2007), situs Pemuteran pada dasamya merupakan pemukiman pantai yang kehidupan masyarakatnya tergantung dari hasil laut. Kehidupan pemukiman di situs ini pun tidak terlepas dari kebutuhan makanan yang berasal dari tumbuhan. Keanekaragaman jenis tumbuhan di wilayah dapat disebabkan oleh campur tangan manusia misalnya dengan menebang atau menanam tumbuhan yang dikehendaki. Berbagai jenis tumbuhan akan tumbuh pada daerah bekas tebangan atau berbagai jenis tumbuhan akan ditanam pada daerah bekas tebangan guna memenuhi kebutuhan hidup.

Berbagai jenis tanaman akan ditanam sesuai dengan kepentingan dan fungsinya dan diharapkan tanaman tersebut dapat berfungsi ganda, misalnya selain sebagai tanaman obat dapat pula dipakai sebagai tanaman hias, maka tanaman akan ditanam di sekitar dapur atau di halaman rumah lainnya. Berbagai jenis tanaman dapat dipakai untuk memenuhi arsitektur, estetika, dan fungsional, juga untuk keperluan upakara dan usada. Pemakaian jenis tanaman tersebut seperti untuk sarana upakara di Bali (Hindu), terdiri dari air, daun, bunga, buah, dan api. Selain unsur api dan air, selebihnya adalah merupakan unsur tanaman. Sloka pada Weda V.11.6 berbunyi: "Tvam agne agniraso guhahitam Anuavidan sinniyanam vanevane" yang artinya kurang lebih bahwa tanaman merupakan ciptaan Tuhan untuk menunjang kebutuhan makhluk hidup termasuk manusia (makan dan keperluan lainnya). Lebih jauh Iontar Bhagawad Gita IX sloka 26 menyebutkan bunga sebagai unsur pokok dalam upakara selain buahbuahan, daun dan air yang bunyinya: Pattram Puspamtoyam Yo me bhakty prayacchati Tad aham bhaktyupahrtam Asn-mi prayat-tmanah yang artinya kurang lebih adalah siapapun dengan kesujudan hati mempersembahkan pada Ku (Tuhan) daun, bunga, buah-buahan dan air, persembahan yang didasari oleh cinta dan keluar dari lubuk hati yang suci, aku terima. Unsur- 
unsur persembahan itu dibentuk sedemikian rupa sehingga menjadi "banten" atau sesaji (sesajen) (Prajoko, A; 2009).

Dari hal tersebut di atas maka dapatlah diartikan bahwa sejak dulu tumbuhan ataupun tanaman tidak terpisahkan dari kehidupan manusia pada umumnya dan khususnya masyarakat Bali. Oleh karena itu untuk mengetahui keanekaragaman jenis tumbuhan di masa lalu tersebut, perlu penelitian pollen sedimen dari situs ini yang akan memberikan sumbangan data berupa jenis tumbuhan yang pernah tersebar di wilayah ini.

\section{LATAR BELAKANG SITUS PEMUTERAN}

Situs Pemuteran merupakan salah situs pada masa prasejarah dengan berbagai aktivitas atau pusat budaya antara lain sistim penguburan di masa lampau. Situs ini terletak di daerah pesisir pantai utara Bali, tepatnya di Desa Pemuteran, Kecamatan Geroggak, Kabupaten Buleleng, Provinsi Bali yang membentang dari utara ke selatan lebih kurang antara $08^{\circ} 08^{\prime} 20,3^{\prime \prime}$ Lintang Selatan - $08^{\circ} 09^{\prime} 14,2^{\prime \prime}$ Lintang Selatan dan antara $114^{\circ} 38 ' 56,6^{\prime \prime}$ Bujur Timur - $114^{\circ} 39^{\prime} 36,7^{\prime \prime}$ dengan ketinggian lebih kurang antara 2 - 90 meter dari permukaan laut.

Sampai saat ini belum ada pertanggalan yang pasti dari situs ini. Kemungkinan pertanggalan situs ini sejaman dengan situs Gilimanuk karena karakter dan asosiasi temuan arkeologisnya menunjukkan keminipan. Berdasarkan pengujian pertaggalan C14, usia rangka manusia yang dikubur dalam strata yang sama menunjukkan hasil yang berbeda yaitu $60-80 \mathrm{SM}, 432-782 \mathrm{M}, 672-953 \mathrm{M}$ dan $660-878 \mathrm{M}$, sehingga dapat diketahui bahwa aktivitas penguburan berlangsung dalam waktu lama dan secara berulang-ulang di lokasi yang sama (Aziz dalam Suastika, 2006).

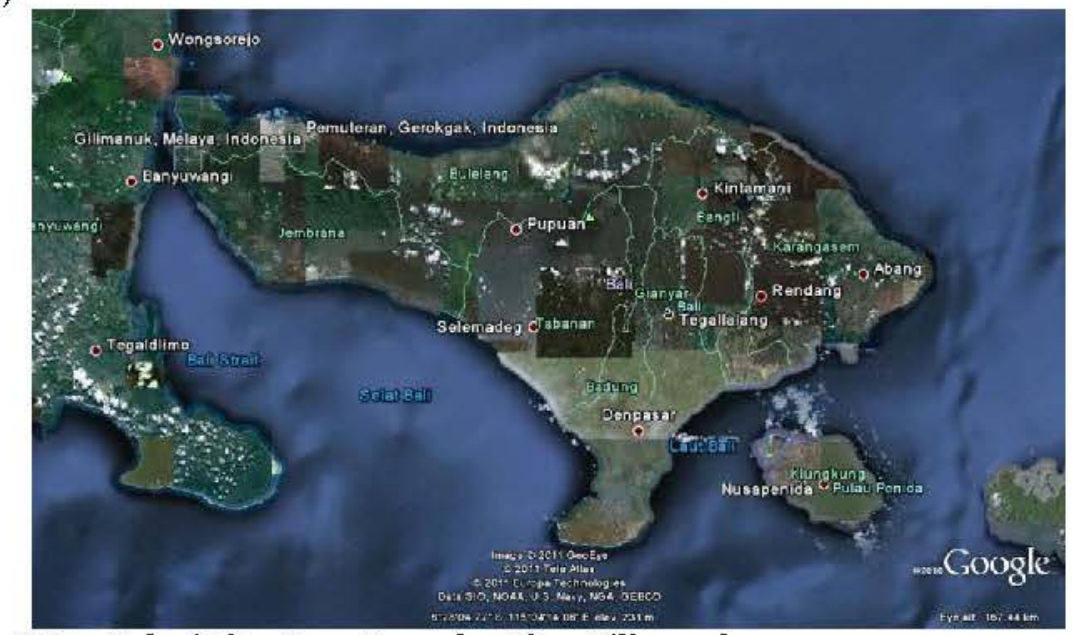

Peta: Lokasi Situs Permateran dan Situs Gilimanuk di Kabupaten Buleleng, Provinsi Bali (sumber: Google, 2011) 
Secara geografis, desa ini dibatasi perbukitan Bukit Beratan di sebelah barat, Bukit Ser di Barat Laut, Bukit Pemuteran/Bukit Ngandang/Bukit Melintang di selatan dan Bukit Pulaki di sebelah Timur, sedangkan dibagian utara merupakan Laut Jawa.

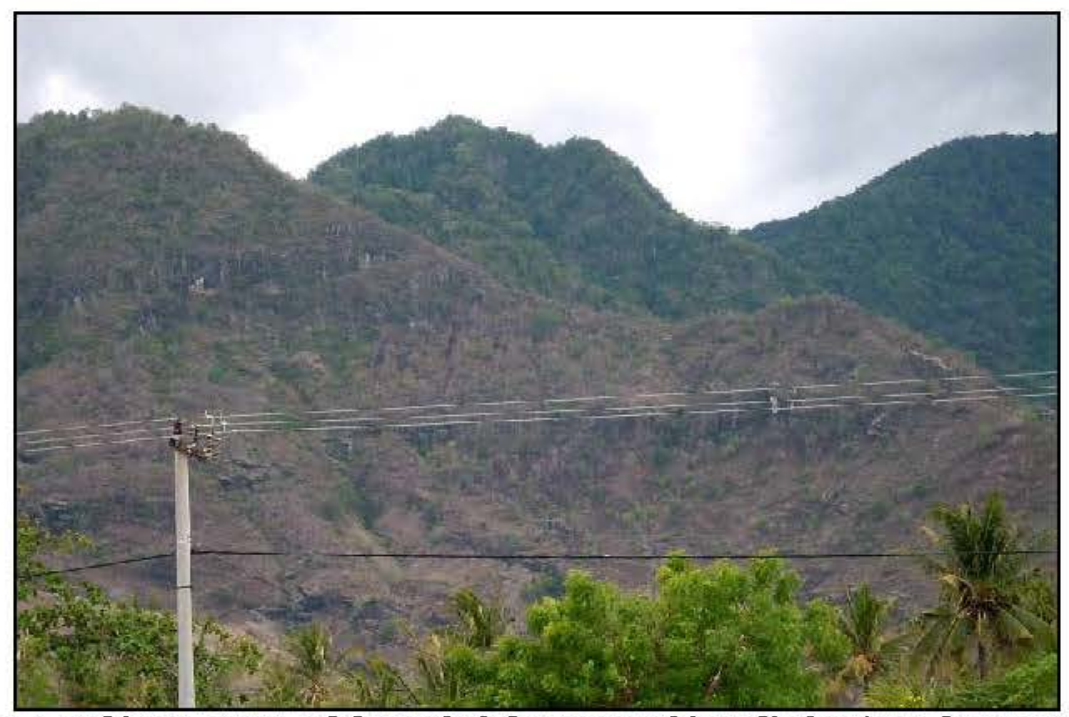

Foto 1. Bukit Perruateran oleh penduduk setempat biasa disebut juga dengan Bukcit Ngandang atau Bukit Melintang yang terletal di sebelah selatan Desa Perruteran

Bentang alam situs Pemuteran merupakan sebuah dataran yang luas, terlindung di balik pagar perbukitan, yang terbentuk oleh endapan

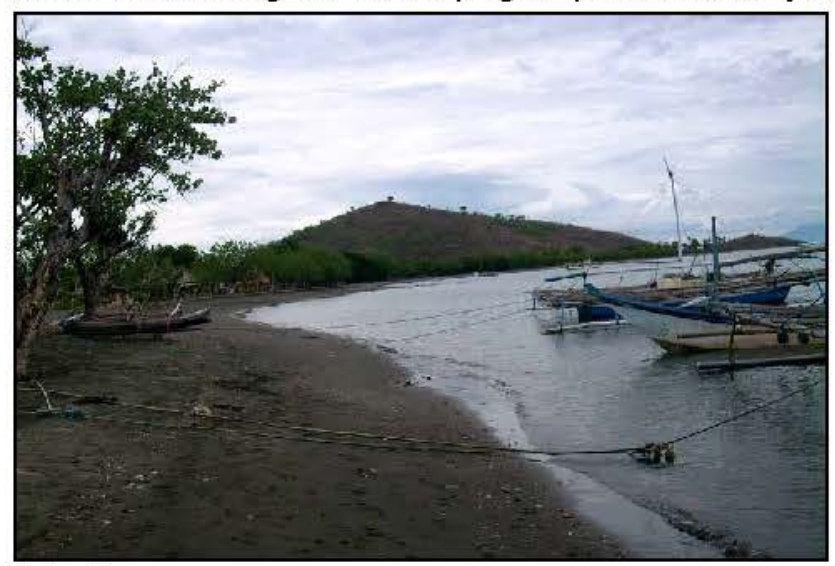

Foto 2.

Bukit Beratan di sebelah barat dan Laut Jawa di bagian Utara Desa Pemuteran. Dikejauhan tampak Bukit Ser.

Dok. Vita, 2007 vulkanik dan endapan gelombang laut. Pada musim kemarau, situs ini menjadi lahan tandus dan kering, dan tidak produktif.

Situs Pemuteran merupakan situs kubur pada masa prasejarah yang berada di pantai utara Bali. Situs ini terletak di desa Pemuteran, Kecamatan Gerokgak, Kabupaten Buleleng, Provinsi Bali.Berbagai temuan arkeologis berupa pecahan periuk dan tempayan telah ditemukan di situs ini. Berdasarkan laporan dari penduduk setempat (Bapak Gandhi dan Sumawi), telah ditemukan 4 rangka manusia dan pada salah satu tangannya ditemukan 7 
mata uang kuno (uang kepeng dengan lubang persegi di tengahnya) didekat rangka tersebut (Triwurjani dan kawan-kawan, 2007). Diketahui bahwa sisa rangka manusia tersebut berasal dari ras Mongolid dan Austramelanisid (Sutaba dalam Triwurjani dkk, 2007).

Menurut Sunarya (2006), pada awalnya mata uang hanya dipakai sebagai alat tukar yang selanjutnya semakin banyak mata uang yang beredar di masyarakat, maka fungsi mata uang mengalami perkembangan. Selain sebagai alat tukar, uang pun menjadi alat pembayaran utama. Berdasarkan data prasasti yang ada, diketahui bahwa penggunaan mata uang oleh masyarakat Bali Kuno telah dilakukan sejak abad IX Masehi. Hal tersebut didasarkan atas pemberitaan prasasti tertua yang ditemukan di Bali yakni prasasti 001 Sukawana Al bertahun 804 Saka. Adapun jenis mata uang yang dimaksud adalah masu (mas suwarna), ma (masaka), ku (kupang), pi (piling), sa (saga) dan perak.

Sebagai situs kubur, maka situs ini juga tidak terlepas dari kondisi lingkungan terutama lingkungan vegetasi di masa lampau. Hal ini diperkuat juga dengan pendapat Djuwita dalam Triwurjani dan kawan-kawan (2007), tanah di wilayah ini kurang subur dengan $\mathrm{pH}$ yang tinggi dan kurang subur sehingga memungkinkan budidaya tanaman tidak dilakukan di daerah ini dan sebagai mata pencaharian, mereka memanfaatkan hasil dari laut. Walaupun demikian, kehidupan mereka di masa lalu tidak terlepas dari berbagai jenis tumbuhan yang tumbuh di sekitar tempat tinggal mereka, baik tumbuhan yang dimanfaatkan sebagai pangan maupun sebagai pelengkap untuk upacara-upacara keagamaan oleh masyarakat Bali pada umumnya ataupun untuk kebutuhan sehari-hari lainnya.

Untuk mengetahui keanekaragaman jenis tumbuhan yang terdapat di situs Pemuteran, Kabupaten Buleleng, Bali ini maka perlu dilakukan penelitian pollen pada sedimen dari situs tersebut guna memberikan sumbangan data berupa jenis tumbuhan yang pernah terdapat di wilayah ini, sehingga jenis tumbuhan yang berkemungkinan dimanfaatkan untuk upacara religi/kegiatan penguburan ataupun untuk kepentingan lainnya dapat diketahui pula.

\section{METODE PENELITIAN}

Untuk mengetahui keadaan lingkungan vegetasi serta keanekaragaman jenis tumbuhan yang ada sekarang, telah dilakukan survei lingkungan di wilayah Situs Pemuteran di Desa Pemuteran Kecamatan Geroggak, Kabupaten Buleleng, Provinsi Bali, sedangkan untuk mengetahui keanekaragaman jenis tumbuhan di masa lampau telah dilakukan analisa palinologi di Laboratorium Puslitbang Arkeologi Nasional dengan berbagai tahap proses. Proses pengeringan sampel tanah, metode HF yaitu penghilangan garam terlarut air, penghilangan unsur silika, pemisahan mineral berat, metode acetolysis, penghilangan asam humat, pewarnaan, penempelan residu, pemeriksaan di bawah mikroskop dan akhirnya 
diidentifikasi dengen buku kunci determinasi, antara lain dari buku How To Know Pollen and Spores (Kapp, R.O, 1968), Pollen Analysis (Moore, Webb dan Collinson, 1978). Metode analisa palinology (analisis serbuk sari/pollen analysis) yaitu metode yang dipakai untuk mengetahui jenis pollen atau serbuk sari tumbuhan yang terkandung dalam sedimen, metode ini juga berguna dalam rekonstruksi flora, vegetasi, dan lingkungan masa lampau.

Berkaitan dengan temuan berbagai fragmen gerabah pada kotak galian tersebut telah dilakukan pengambilan sampel di sekitar temuan gerabah serta pada kotak-kotak ekskavasi yang telah dibuka di Situs Pemuteran, Kabupaten Buleleng, Provinsi Bali secara stratifified random sampling.

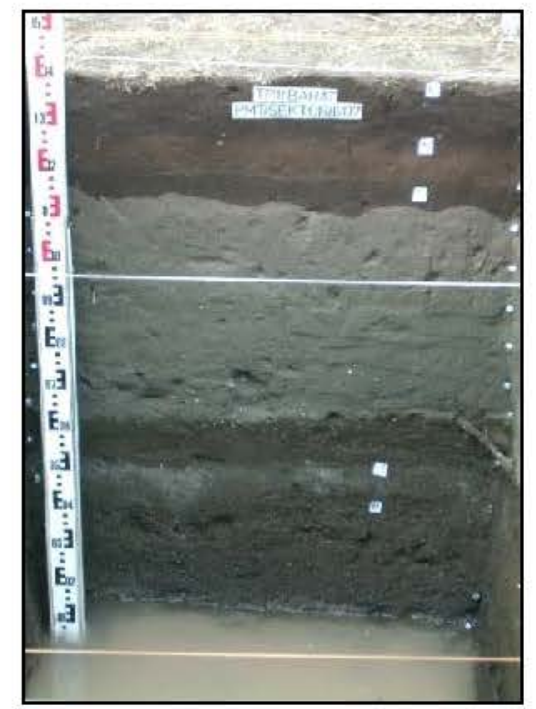

* Pengambilan sampel tanah dilakukan di sektor II pada kotak TP1, pada kotak TP1 terdapat 5 lapisan tanah. Pengambilan sampel tanah dilakukan berdasarkan lapisan strata tanah pada dinding barat kotak TP 1 yang dimulai dari lapisan paling bawah (lapisan E) yaitu pada kedalaman $115 \mathrm{~cm}$, untuk selanjutnya tanah diambil pada lapisan D (101 $\mathrm{cm})$, lapisan $C(32 \mathrm{~cm})$, lapisan B $(25$ $\mathrm{cm})$ dan lapisan $A(14 \mathrm{~cm})$

Dok Vita, 2007

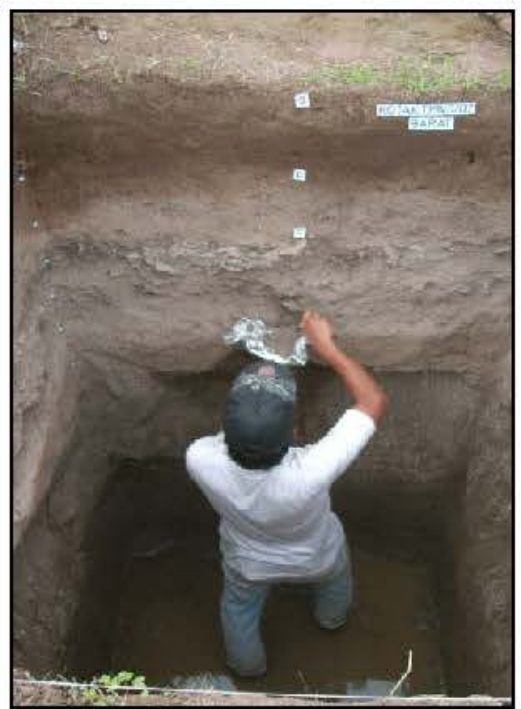

* Pengambilan sampel tanah pada kotak TP5 yang terdapat di sektor I; pada kotak TP5 terdapat 6 lapisan tanah. Pengambilan sampel tanah pada kotak TP5 dilakukan berdasarkan lapisan strata tanah pada dinding selatan kotak TP5 yang dimulai dari lapisan paling bawah (lapisan F) yaitu pada kedalaman 190 $\mathrm{cm}$ dari permukaan tanah.

Dok Vita, 2007 
Untuk selanjutnya pengambilan sampel tanah dilakukan pada lapisan $E$ $(125 \mathrm{~cm})$; lapisan D $(82 \mathrm{~cm})$; lapisan $(47 \mathrm{~cm})$, lapisan B $(39 \mathrm{~cm})$ dan lapisan A $(22 \mathrm{~cm})$.

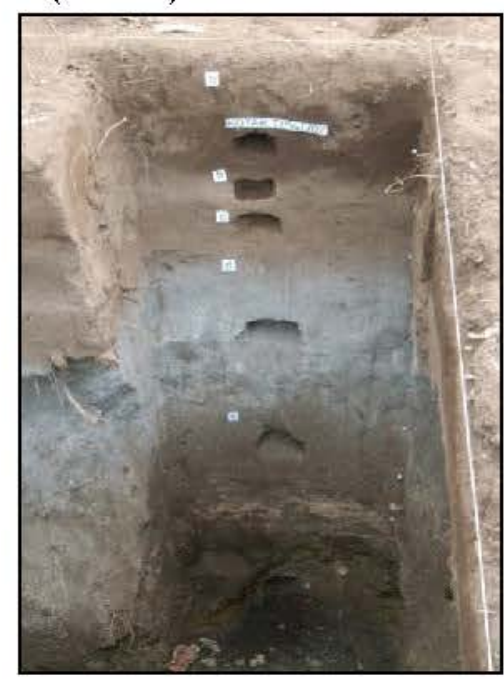

* Pada kotak IV sektor 1 terdapat 6 lapisan tanah, pengambilan sampel tanah pada kotak TP4 sektor I dilakukan pada lapisan $\mathrm{F}$ pada kedalaman $190 \mathrm{~cm}$, untuk selanjunya pengambilan sampel tanah pada lapisan E $(134 \mathrm{~cm})$, lapisan D $(89 \mathrm{~cm})$, lapisan $C(64 \mathrm{~cm})$, lapisan $B(31 \mathrm{~cm})$, dan lapisan $A(10 \mathrm{~cm})$

Dok Vita, 2007

Pengambilan

sampel tanah selanjutnya dilakukan di antara celah pada tempat pengambilan batu pada kedalaman $15 \mathrm{~cm}$, $50 \mathrm{~cm}$ dan $100 \mathrm{~cm}$

Dok Vita, 2007
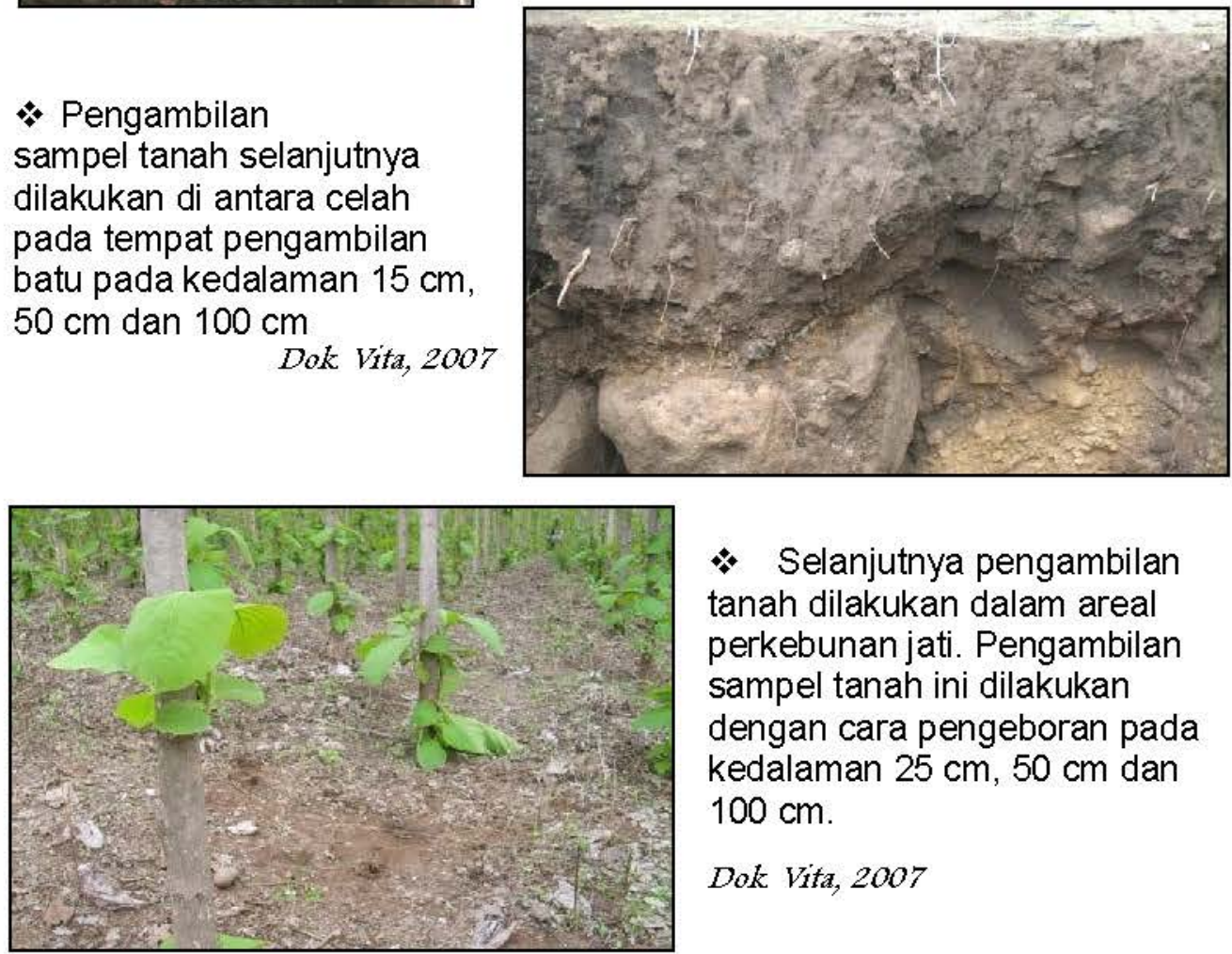

* Selanjutnya pengambilan tanah dilakukan dalam areal perkebunan jati. Pengambilan sampel tanah ini dilakukan dengan cara pengeboran pada kedalaman $25 \mathrm{~cm}, 50 \mathrm{~cm}$ dan $100 \mathrm{~cm}$.

Dok Vita, 2007 


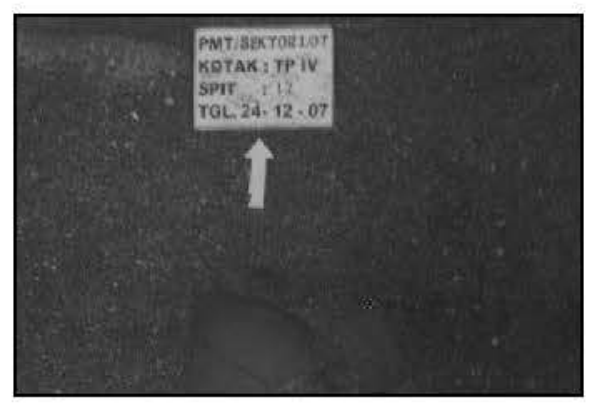

Tanah yang terdapat dibawah pecahan gerabah yang terletak pada kotak TP IV spit $12(180 \mathrm{~cm})$.

Dok. Vita, 2007

\section{KEANEKARAGAMAN JENIS TUMBUHAN DI SITUS PEMUTERAN}

\section{A. Lingkungan Vegetasi Situs Pemuteran}

Secara biologi, karakteristik pesisir dapat diketahui dari persebaran biota pantai ke arah darat, baik persebaran vegetasi maupun persebaran hewan pantai. Kawasan pantai merupakan suatu kawasan yang indah dengan pemandangan yang mempesona, misalnya garis batas pandang dan tenggelamnya matahari di waktu senja (sunset). Namun, jarang sekali orang memperhatikan tumbuh - tumbuhan yang ada di sekitar pantai, yang dari jauh sekilas hanya merupakan semak belukar yang tidak terawat dan tidak berfungsi.

Sebagai daerah pantai maka kawasan pantai memiliki fungsi sebagai sistem penyangga kehidupan, yaitu suatu proses alami dari berbagai unsur hayati dan non hayati yang menjamin kelangsungan kehidupan makhluk, terutama di kawasan pantai dan sekitarnya. Sebagai daerah pengontrol siklus air dan proses intrusi air laut, keberadaan vegetasi di wilayah Pantai akan menjaga ketersediaan cadangan air permukaan yang mampu menghambat terjadinya intrusi air laut ke arah daratan. Kerapatan jenis vegetasi pantai dapat mengontrol pergerakan material pasir akibat pergerakan arus setiap musimnya. Kerapatan jenis vegetasi dapat menghambat kecepatan dan memecah tekanan terpaan angin yang menuju ke pemukiman penduduk.

Adapun jenis tumbuhan yang khas di daerah pantai berpasir ini adalah rumput angin (Spinifex littoreus). Secara umum keadaan lingkungan Situs Pemuteran ini terdiri dari daerah pantai dan perbukitan. Dari hasil survei serta pengamatan yang dilakukan di Situs Pemuteran dapat dilihat bahwa mata pencaharian sebagian besar penduduk Desa Pemuteran berupa nelayan yang bermukim di daerah-daerah pesisir. Hanya sebagian kecil dari masyarakat ini yang bekerja sebagai petani. Hal ini mungkin disebabkan oleh karena kondisi tanah di desa ini sangat sulit untuk ditanami karena kurang subur (tanah berpasir). atas:

Secara fisiognomi lingkungan tumbuhan di situs ini dapat dibagi

a. Lingkungan vegetasi pantai berpasir;

b. Lingkungan vegetasi tanaman pertanian/perkebunan; 
c. Lingkungan vegetasi penghijauan/semak belukar;

d. Lingkungan vegetasi tanaman pekarangan.

\section{Lingkungan vegetasi pantai berpasir.}

Pantai berpasir di situs ini merupakan pantai yang didominasi oleh hamparan pasir yang merupakan daerah perbatasan antara ekosistim darat dan ekosistim laut yang mana pada areal/kawasan pantai mempunyai jenis flora yang khas dan sangat berbeda dengan jenis flora yang terdapat pada daerah pedalaman. Jenis flora pantai berhubungan dengan aneka bentuk pantai, dari yang landai dan lebar, baik yang kering maupun yang berawa sampai yang curam dan berbatu-batu serta mempunyai kadar garam yang tinggi didalam tanah yang megakibatkan hanya tumbuhan tertentu pula yang dapat menyesuaikan diri dengan keadaan seperti ini dapat hidup subur.

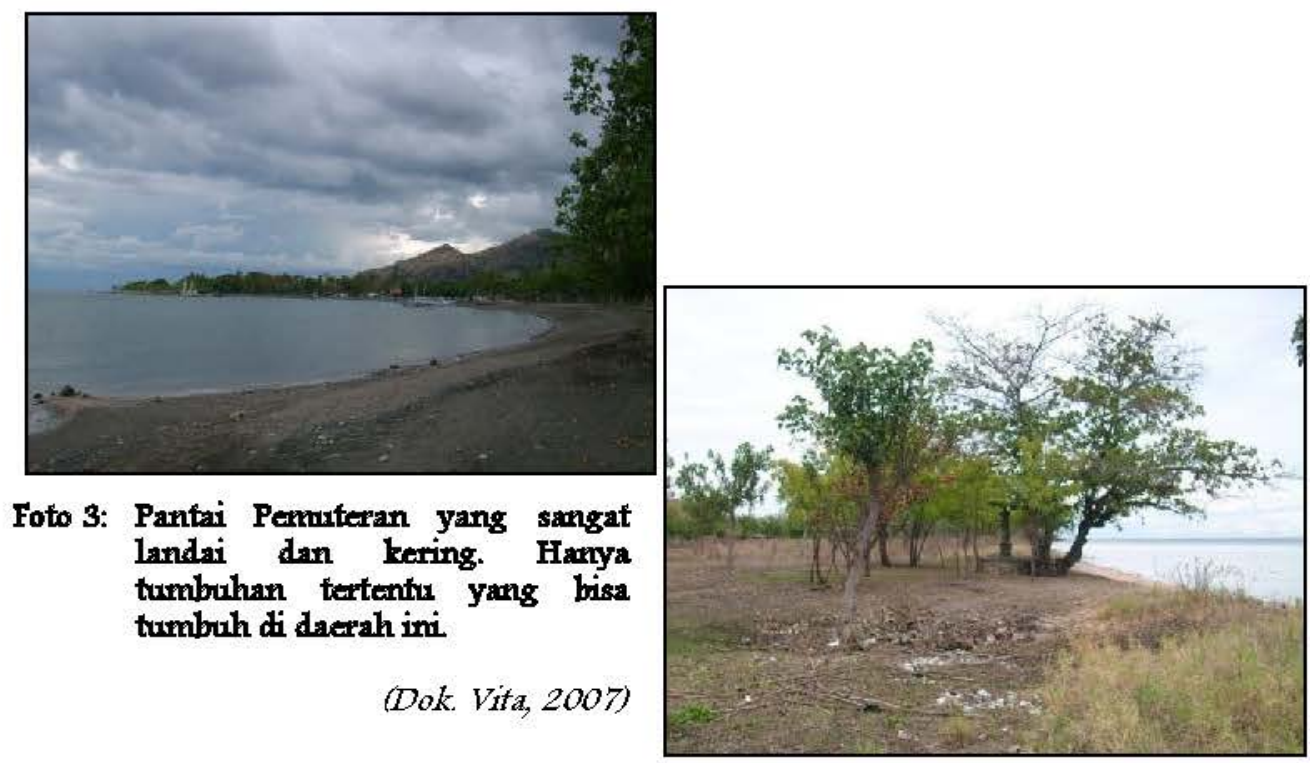

Tumbuhan pantai akan beradaptasi dengan habitatnya dengan berbagai cara. Salah satunya yaitu dengan cara menebalkan daun, daun tumbuhan pantai pada umumnya tebal, mengkilat dan kaku yang berguna untuk mengurangi penguapan yang terlampau besar karena teriknya panas matahari, disamping itu karena keadaan tanah/habitat yang berupa pasir ini tidak stabil, lepas dan sangat dipengaruhi oleh angin yang berhembus dengan kencang maka untuk memperoleh pegangan yang kuat dalam pasir, maka pada setiap ruas/buku batang akan keluar akar-akar yang masuk kedalam tanah.Jenis tumbuhan disepanjang pantai ini tidak begitu bervariasi. Jenis tumbuhannya didominasi oleh waru (Hibiscus tiliaceus), waru lot (Thespesia populnea), pandan duri (Pandanus tectorius), kelapa (Cocos nucifera), lontar (Borassus flabelifer), bekul (Ziziphus jujuba), pohon santan (Lannea coromandelica), ketapang (Terminalia catappa). 
Berdasarkan hasil survei tersebut dapat juga dilihat bahwa kelompok tumbuhan terdepan yang terletak di belakang garis pantai adalah dari jenis rumput angin (Spinifex littoreus), rumput tembaga (Ischaemum muticum), dan teki laut (Cyperus maritima). Pada umumnya rumput-rumput ini tumbuh menjalar di atas pasir.

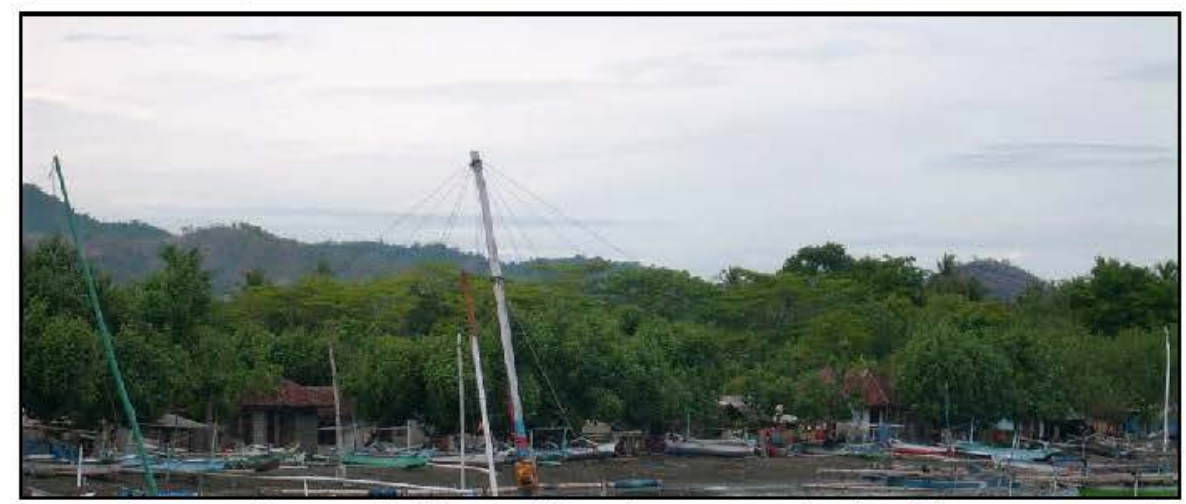

Foto 4: Jenis waru (Fibiscus tiliscesas) yang mendominasi kawasan pantai Desa Penuteran.

Dok. Vita, 2007

Beberapa jenis tumbuhan yang mencirikan vegetasi pantai berpasir yaitu terdapatnya jenis pandan berduri (Pandanus tectorius), kaktus (Opuntia elatior), bakung (Crinum asiaticum), rumput angin (Spinifex litoralis), kelapa (Cocos nucifera) sedangkan pada formasi Baringtonia dijumpai berbagai jenis tumbuhan pantai yang didominasi oleh jenis Baringtonia asiatica

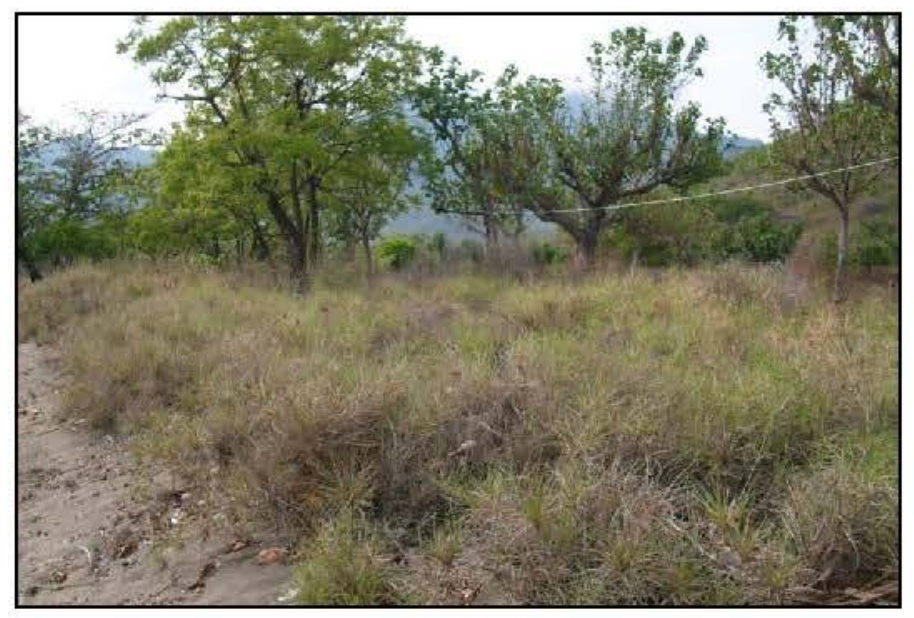

Foto 5: Rumput angin berasosiasi dengan rumput tembaga dan teki laut mendominasi areal pantai berpasir.

Dok. Vita, 2007 

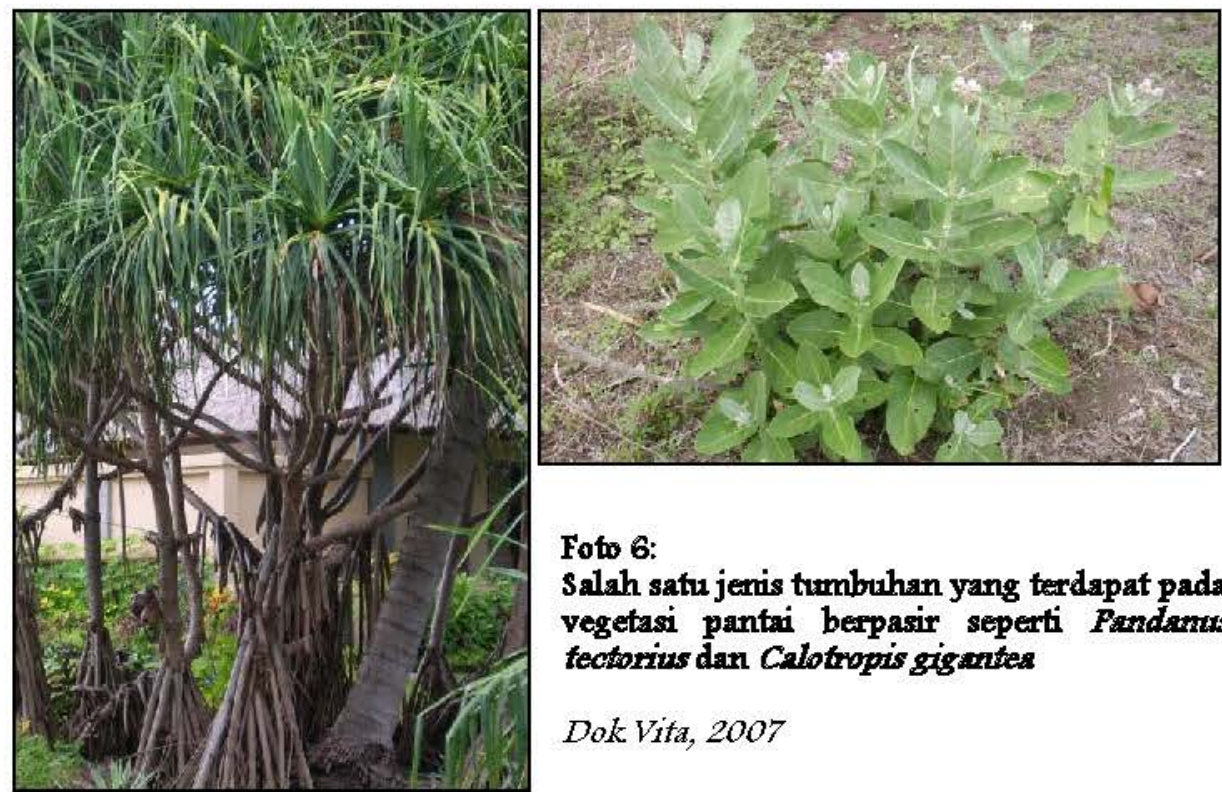

Foto 6:

Salah satu jenis tumbruhan yang terdapat pada vegetasi pantai berpasir seperti Pandanus tectorius dan Calotropis gigantea

Dok Vita, 2007

\section{Lingkungan Vegetasi Tanaman Pertanian/Perkebunan}

Lingkungan Desa Pemuteran merupakan desa yang cukup minus terhadap tanaman pertanian. Hal ini disebabkan keadaan tanah di desa ini tidak mendukung untuk pertanian. Desa ini terletak di wilayah pantai berpasir yang bersifat lepas dan sangat dipengaruhi oleh angin yang berembus, maka pembentukkan humus pun masih jauh dari sempurna, sehingga keadaan seperti ini tidak mendukung untuk pertanian, akibatnya masyarakat setempat banyak beralih sebagai nelayan.

Satu-satunya usaha pertanian yang mereka lakukan adalah dengan bertanam jagung (Zea mays) yang merupakan salah satu makanan pokok penduduk setempat. Selain jagung sebagai usaha pertanian masyarakat setempat, mereka juga menam jenis kacang-kacangan dari jenis kacang koro (Phaseolus lunatus) sebagai tanaman selingan. Jagung dan kacang merah atau koro bukan tanaman asli wilayah Indo Pasific. Bukan native tanaman Bali juga. Kemungkinan dibawa oleh kolonial. Sesuai dengan kondisi tanah daerah setempat, maka tanaman jagung dapat lebih subur tumbuh di desa ini, menurut Ismal (1995, 146-147) Jagung dapat tumbuh pada ketinggian $0-4000$ meter dari muka laut di daerah tropic. Dapat juga tumbuh pada berbagai tipe tanah di darah lintang dari $58^{\circ}$ Utara $-40^{\circ}$ Selatan. Penyebaran tanaman jagung sangat dibatasi oleh toleransinya terhadap suhu dan curah hujan. Suhu yang dikehendaki oleh jagung untuk berkecabah dan pertumbuhan adalah optimum $27^{\circ}-23^{\circ} \mathrm{C}$, namun dapat tumbuh dengan kisaran suhun $10^{\circ} \mathrm{C}-43^{\circ} \mathrm{C}$, sedangkan curah hujan selama pertumbuhan adalah minimum $200 \mathrm{~mm} /$ tahun dan maksimum 1500 $\mathrm{mm} /$ tahun dan optimum $400-600 \mathrm{~mm} /$ tahun. Jagung dapat tumbuh baik pada tanah-tanah yang drainesenya baik selama musim hujan. Dengan 
persyaratan yang demikian, tanaman ini pun dapat tumbuh pada tanah liat berlempung atau lempung berpasir, sama halnya dengan tanaman kacangkacangan, untuk bertanam kacang-kacangan memerlukan kondisi tanah

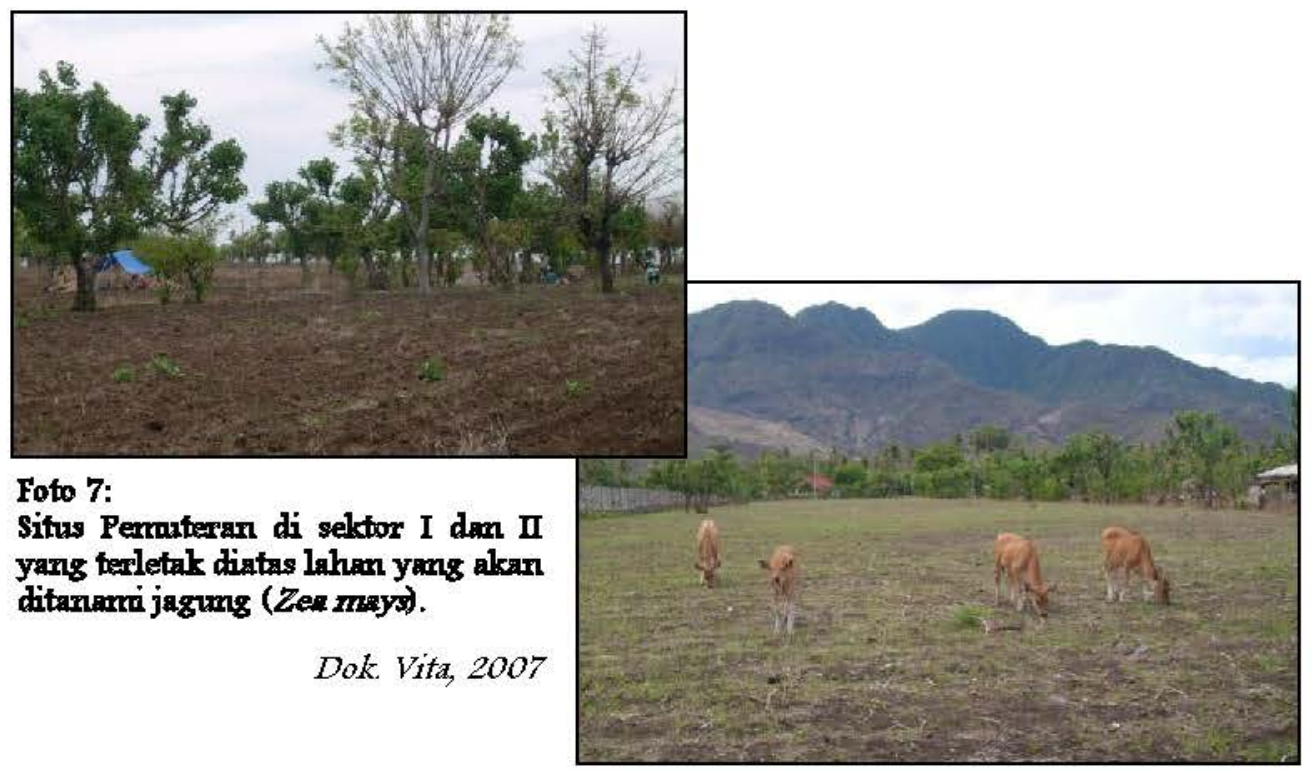

yang hampir sama juga dengan jenis jagung. Tanaman kacang sangat menyenangi cuaca panas dengan curah hujan yang moderat. Jenis kacangkacangan menyukai cahaya matahari yang banyak, tanah berpasir serta drainase yang cukup. Jenis ini tidak menyukai tanah yang asam. Jika drainase baik, maka jenis ini dapat tumbuh pada tanah lempung dan alluvial. Selain tanaman jagung dan kacang-kacangan, jenis tanaman lain yang diusahakan dengan kondisi tanah seperti di Desa Pemuteran ini adalah tanaman mangga (Mangifera indica) dan jati (Tectona grandis).

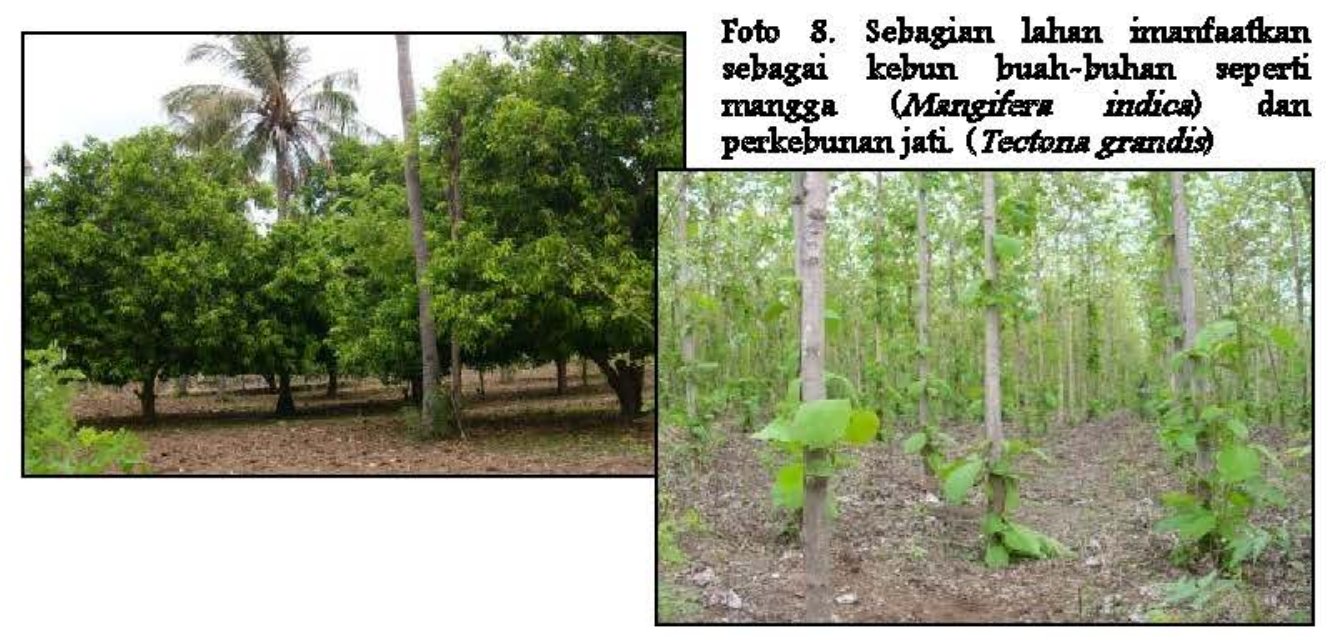

Dok. Vita, 2007 


\section{Lingkungan tanaman penghijauan/semak belukar}

Dari pengamatan lingkungan di situs ini nampak bahwa lingkungan situs ini sangat gersang, dan jarang dijumpai tumbuhan semak belukar, karena tanah di desa ini bersifat lepas dan sangat sulit untuk ditanami, selain itu untuk pembentukkan humus juga sulit karena iklim di daerah ini lebih dipengaruhi oleh angin. Oleh karena itu, untuk mengurangi erosi baik pada daerah perbukitan maupun pada daerah yang landai, maka masyarakat setempat mengupayakan/mencoba untuk melakukan penghijauan pada tanah-tanah karstis.

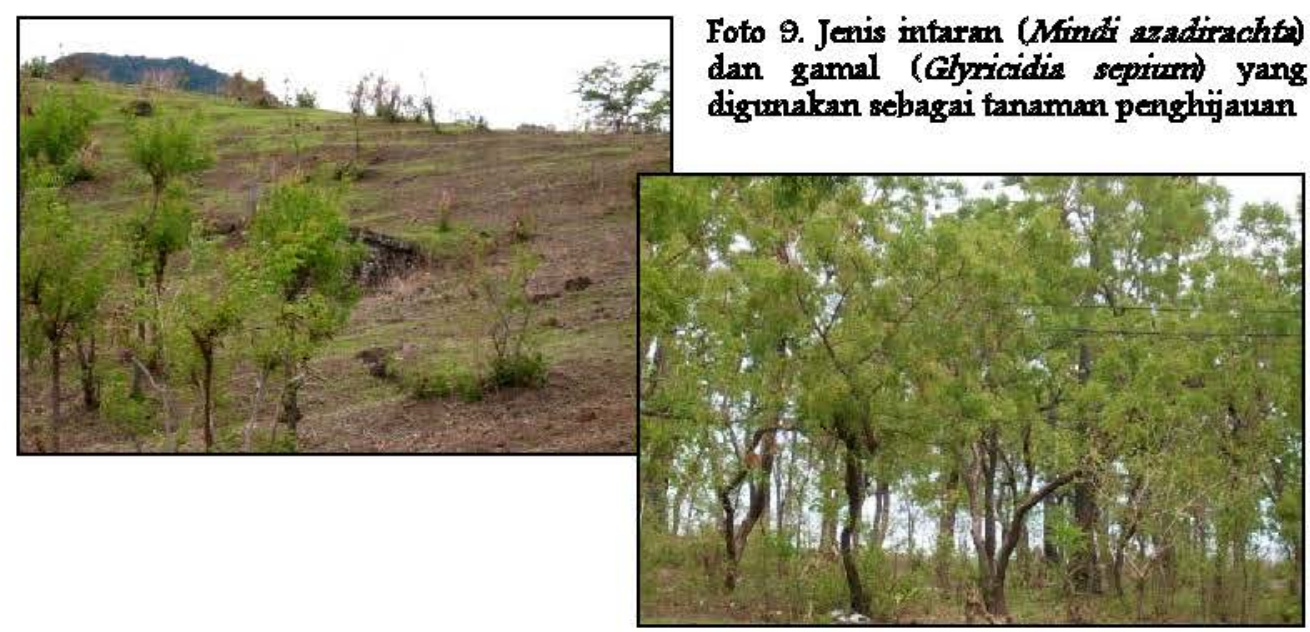

Dok. Vita, 2007

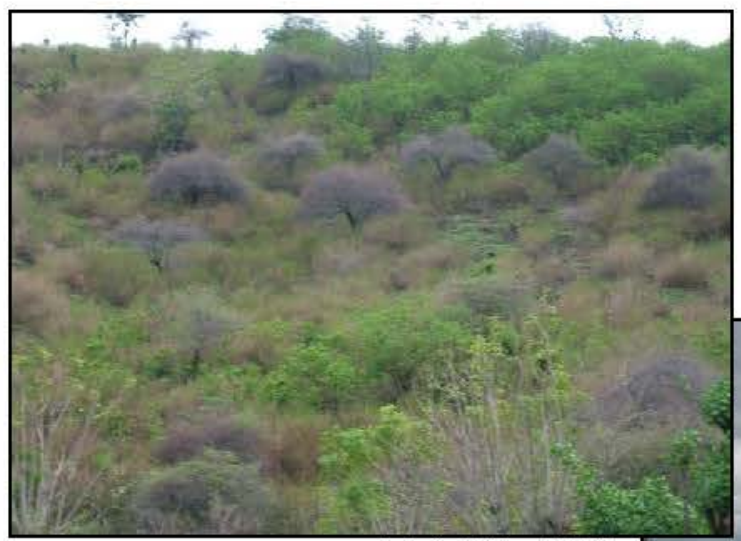

Foto 10.

Vegetusi bekul (Ziziphuss jugiuba) sebaggi tranaman penghijauan di Bukit Beratan dm warn (H. titiacenso) urituk di pantai-partai

Dok Vita, 2007

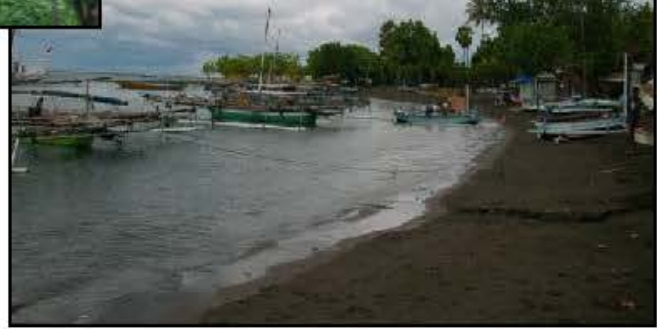


Jenis tanaman yang digunakan untuk penghijauan adalah jenis gamal (Glyricidia sepium), entiran (Mindi azadirachta), terutama pada daerah pedataran dan lereng-lereng perbukitan yang letaknya berjauhan dari garis pantai, dan tumbuhan bekul (Zizipus jujuba) pada daerah perbukitan dekat pantai (Bukit Beratan) yang mana kondisi tanahnya pasir berbatu dan tumbuhan waru (Hibiscus tiliaceus) di pantai-pantai terbuka.

\section{Lingkungan vegetasi tanaman pekarangan}

Dari hasil pengamatan dapat dilihat bahwa tampaknya masyarakat setempat tidak terlepas dari berbagai jenis tanaman pekarangan terutama tanaman yang menghasilkan bunga. Hal ini mungkin disebabkan karena penduduk di daerah ini pada umumnya beragama Hindu, yang untuk sesajian ataupun untuk upacara agama selalu disertai dengan beraneka macam jenis bunga. Berbagai jenis tanaman pekarangan yang mereka tanam antara lain kamboja (Plumiera acuminata, Plumiera rubra), bogenvil (Bougainvillea spectabilis), melati (Jasminum sambac), kenanga (Canangium odoratum), kembang merak (Caesalpinia pulcherima), kembang sepatu (Hibiscus rosa-sinensis) dan lain sebagainya.

\section{B. Keanekaragaman jenis tumbuhan dimasa lampau berdasarkan analisis palinology.}

Dari hasil analisis laboratoris terhadap sampel tanah, cukup banyak didapatkan fosil pollen dalam keadaan yang sulit untuk diidentifikasi, karena kondisi butiran pollen yang rusak akibat tidak terawetkan. Tidak terawetkannya butiran pollen ini dapat disebabkan oleh kondisi sedimen yang banyak mengandung pasir yang bersifat basa. Berdasarkan analisis tanah yang telah dikejakan berdasarkan segitiga tekstur, terbukti bahwa sedimen (tanah) di desa ini sangat didominasi oleh jenis pasir ( $40 \%$ sampai $97,5 \%$ ). Kemungkinan hal inilah yang menyebabkan butiran polen tidak terawetkan, sehingga jenis butiran fosil pollen yang didapatkan tidak banyak dan tidak begitu bervariasi. Beberapa butiran pollen yang berhasil diidentifikasi yaitu berasal dari jenis tumbuhan Compositae, Cactaceae, Poaceae, Malvaceae, Cyperaceae, Papilionaceae Verbenaceae, Pinaceae, Fagaceae, Daphnae, Sequoia, Geranaceae, Cupresus. 


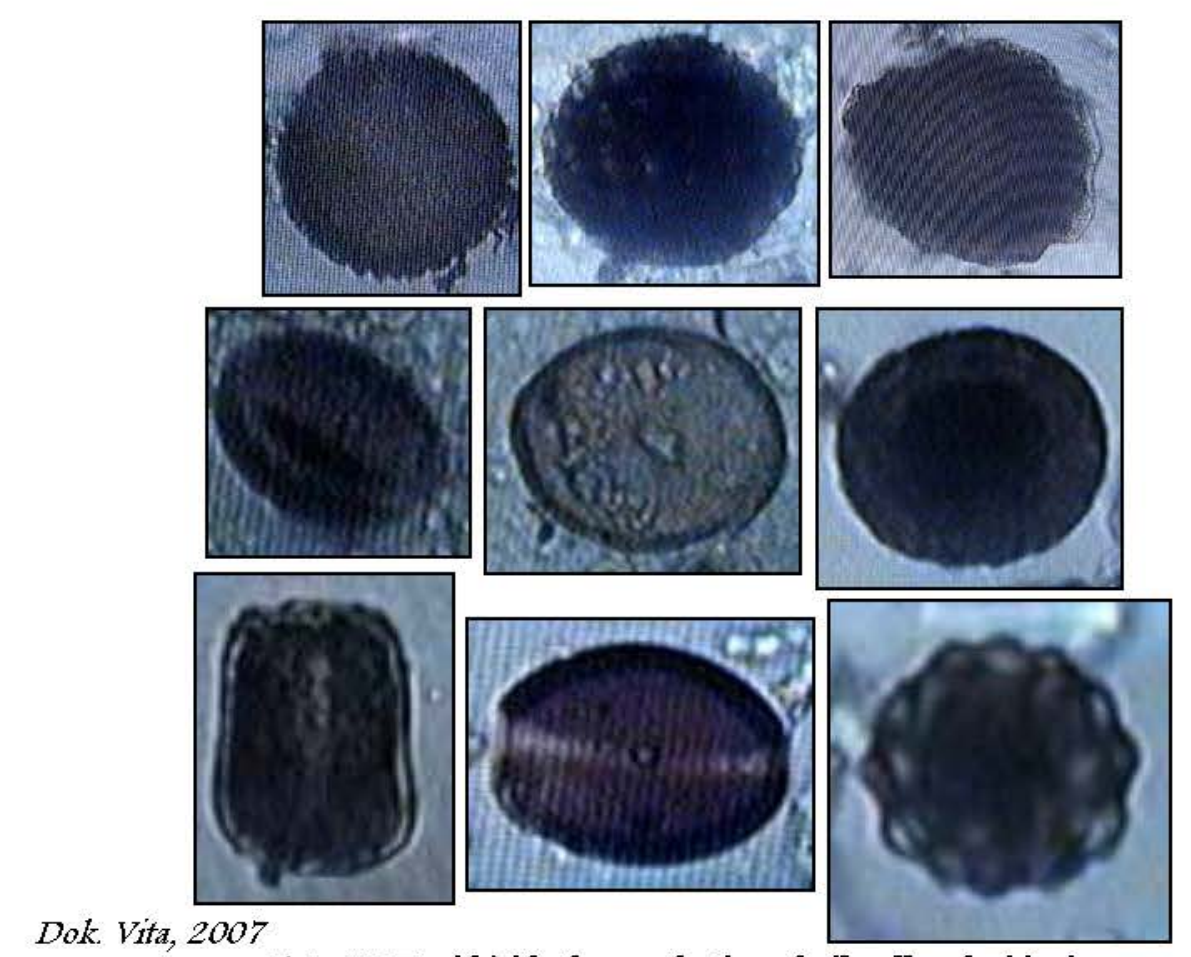

Dok. Vita, 2007
Foto 11. Dari kiri ke kanan: butiran fosil pollen dari jenis
Mahracene, Prpzitionacene, Cactraene, Cyperacene,
Poncene, Finnceas, Verberncene, Poncene, Compositue

Dari jenis-jenis fosil pollen yang didapatkan, terdapat beberapa jenis fosil pollen yang didapatkan di sekitar pecahan gerabah, seperti butiran pollen dari jenis Compositae, Poaceae, Malvaceae dan Papilionaceae yang berkemungkinan jenis-jenis tersebut dimanfaatkan untuk upacara religi dan berkemungkinan juga pada saat itu lingkungan vegetasi di wilayah ini terdiri dari jenis-jens tersebut. Dikatakan demikian karena banyak di antara jenisjenis tumbuhan tersebut yang cukup bermanfaat dalam kehidupan masyarakat, yang jenis-jenis tersebut merupakan jenis tumbuhan dari kelompok tumbuhan berbunga cukup indah, seperti jenis tumbuhan dari suku Compositae merupakan tumbuhan perdu atau semak dan jarang sekali ditemukan berupa pohon. Marga dari suku Compositae ini banyak yang bermanfaat sebagai penghasil obat, sebagai tanaman hias seperti Eupathorium inulifolium, bunga aster dan lain-lain. Suku Poaceae disebut juga suku Graminae, dapat berupa semak maupun pohon yang tinggi, misalnya jenis-jenis bambu, tebu, jagung, padi gandum serta berjenis-jenis rumput lainnya termasuk jenis ilalang, Suku Malvaceae disebut juga suku kapas-kapasan dan banyak diantara suku ini merupakan tanaman budidaya yang penting seperti kapas serta banyak pula yang merupakan tanaman hias antara lain kembang sepatu, waru dan lain-lain. Suku Papilionaceae disebut juga suku polong-polongan yang merupakan tanaman penghasil komoditi yang berharga, merupakan bahan pangan dengan nilai gizi yang 
tinggi karena banyak mengandung lemak dan vitamin-vitamin. Marga dari jenis ini banyak juga digunakan untuk berbagai keperluan selain sebagai bahan pangan juga diigunakan untuk makanan ternak, bahan industri, bahan bangunan, bahan obat, tanaman hias dan pupuk hijau. Sebagai contoh dari suku ini yaitu kacang tanah, kedelai, petai, jengkol, pohon asam jawa, flamboyan, kembang telang, kembang merak, kecipir, acasia, allpukat dan lain-lain.

Suku Cactaceae merupakan jenis kaktus yang dapat hidup pada tanah-tanah kering. Hal tersebut karena sifat tumbuhan ini banyak menyimpan cadangan air, sehingga tumbuhan ini dapat hidup di daerahdaerah yang sedikit mengandung air. Adapun suku Cyperaceae termasuk golongan rumput-rumputan yang menyukai daerah lembab, berpaya-paya atau berair bahkan di pantai-pantai yang berpasir.

Berdasarkan pada butiran-butiran pollen yang didapatkan tersebut, terdapat juga beberapa jenis tumbuhan yang tidak ditemukan lagi saat ini seperti tumbuhan yang berasal dari famili Pinaceae, Fagaceae, Daphnae, Sequoia, Geranaceae, Cupressus. Jenis-jenis fosil pollen yang tidak terdapat saat ini mungkin butiran pollen tersebut berasal dari daerah lain yang diterbangkan angin hingga sampai di wilayah ini, atau kemungkinan merupakan salah satu tumbuhan yang terdapat di wilayah ini.

Suku Pinaceae (suku tusam-tusaman) merupakan jenis Pinus merkusii, sedangkan suku Fagaceae merupakan jenis pohon yang menurut Tjitrosoepomo (1993) pada jaman dulu jenis dari suku ini terutama dari salah satu jenis dari marga Quercus digunakan sebagai salah satu ramuan dalam pembuatan banyon yang digunakan untuk menghitamkan gigi (sisig).

\section{KESIMPULAN}

Dari hasil analisis laboratoris yang telah dilakukan, maka dapat disimpulkan bahwa:

1. Hasil analisa palinologi terhadap sampel tanah didapatkan keanekaragaman jenis butiran fosil pollen yang berasal dari tumbuhan yang cukup bermanfaat dari famili Compositae, Poaceae, Malvaceae dan Papilionaceae, selain itu terdapat juga butiran pollen yang saat ini tidak terdapat di sekitar situs Pemuteran, seperti famili Pinaceae, Fagaceae, Daphnae, Sequoia, Geraniaceae, Cupressus.

2. Saat ini jenis tumbuhan yang berasal dari jenis pollen tersebut sebagian tidak ditemukan di daerah ini, kemungkinan adanya pollen dari jenis Daphnae, Fagaceae, Sequoia, Cupressus tersebut di wilayah ini disebabkan oleh adanya angin yang menerbangkan butiran pollen ini sampai ke Pemuteran. Jenis-jenis tersebut umumnya banyak berkembang di daerah utara (dingin) seperti Cina.

3. Jika dilihat secara global maka situs Pemuteran ini terletak di pantai Utara Bali tepatnya berada di Desa Pemuteran, Kecamatan Grokgak, 
Kabupaten Buleleng, Provinsi Bali yang pada saat ini terdapat beberapa lingkungan vegetasi yaitu:

$>$ Lingkungan vegetasi pantai berpasir

Lingkungan vegetasi tanaman pertanian/perkebunan

$>$ Lingkungan vegetasi penghijauan/semak belukar

$>$ Lingkungan vegetasi tanaman pekarangan 


\section{KEPUSTAKAAN}

Ismal, Gazali, 1995. Ekologi Tumbuhan dan Tanaman Pertanian. Padang: Penerbit Angkasa Raya Padang

Kapp, Ronald. O. 1968. Polen and Spores. Dubuqua, lowa: W.M. C.Brown Company Publisher

Mahaviranata, Purusa. 1992. "Kubur Terbuka Masa Prasejarah, Kalanganyar, Buleleng". Seri Penerbitan Forum Arkeologi. Tahun III Nomor IV. Januari 1992. Balai Arkeologi Denpasar.

Prajoko, Ahmad. 2010. "Pertamanan Tradisional Bali Berlandaskan Unsur Satyam, Siwam, Sundaram, Relegi dan Usada". Paris Sweet Home Rosentalweg 9, 6340 Baar, Switzerland Firma-ID-No.: CH170.2.000.982-1

Paris Sweet Home @ 2010. All rights reserved.

http://www.parissweethome.com/bali/cultural_my.php?id=11

Suantika, I Wayan. 1998. "Kawasan Pantai Utara Bali, Makna dan Peranannya Dalam Persentuhan Budaya di Masa Lampau". Forum Arkeologi. ISSN 0854-3233. Juli 1998. Denpasar: Balai Arkeologi.

Suastika, I Made. 2006. "Orientasi Kubur Dalam Dimensi Ruang di Bali". Forum Arkeologi, ISSN 0854-3232 No. II. Oktober. Denpasar: Balai Arkeologi.

Sunarya, I Nyoman. 2006. "Aktivitas Perdagangan Masyarakat Kintamani dan Sekitarnya pada Masa Bali Kuno (Kajian Data Prasasti)". Forum Arkeologi, ISSN 0854-3232 No. II. Oktober. Denpasar: Balai Arkeologi.

Tjitrosoepomo. G., 1993. Taksonomi Tumbuhan. Yogyakarta: Gajahmada University Press

Triwurjani dkk. 2007. Penelitian Arkeologi di Situs Pemuteran Pantai Utara Bali, Kecamatan Gerokgak, Kabupaten Buleleng, Provinsi Bali. Jakarta: Pusat Penelitian dan Pengembangan Arkeologi Nasional. Departemen Kebudayaan dan Pariwsata.

Webb, J.A.B. Sc \& Moore P.D., 1978. An Illustrated Guide to Pollen Analysis. London - Sydney., Aucklan - Toronto. Hodder and Stoughton 